\title{
"WHITMAN, THE GREAT POET, HAS MEANT SO MUCH TO ME": LAWRENCE'S STUDIES IN CLASSIC AMERICAN LITERATURE, 1919-1923
}

\author{
M. Wynn ThOMAs AND John TuRneR
}

D. H. Lawrence, Studies in Classic American Literature, edited by Ezra Greenspan, Lindeth Vasey, and John Worthen. The Cambridge Edition of the Works of D. H. Lawrence. Cambridge: Cambridge University Press, 2003. $1 \mathrm{xxx}+632 \mathrm{pp}$.

The latest volume in the magisterial Cambridge series of the works of D.H. Lawrence is Studies in Classic American Literature, a seminal text of modern American literary studies. The comprehensiveness of the materials included in this definitive edition is succinctly indicated on the dust-jacket:

This volume offers the final 1923 version of the text in a newly corrected and uncensored form; it contains the complete surviving 1918-19 text of the essays of the English Review period, including two previously unpublished essay versions; it offers five previously unpublished essays from 1919, as well as a host of other materials (for example, four different versions of Lawrence's pioneering essay on Whitman are included). ${ }^{1}$

Other notable features include explanatory notes, a listing of textual variants, and an outstanding introduction. Of particular interest to Whitman scholars are three earlier versions of Lawrence's celebrated 1923 essay, including the previously unpublished 1919 version, the earliest to have survived. This early version is sensationally different from the essay in its final form and, read in conjunction with the others, allows us to keep closer track than ever before of Lawrence's changing attitudes towards the work of a poet who haunted his imagination. Our purpose here is to trace these changing attitudes to Whitman through the four different versions of the essay, and to show something of the ways in which Whitman informed Lawrence's creative thinking and writing at this critical stage of his development as a novelist. We begin, however, by recalling the arresting character of Studies in Classic American Literature in its final, influential form. 
What a seemingly mad and frequently maddening work the 1923 Studies is, to be sure, and what a tangled history was the process of its making, as this landmark volume makes wonderfully clear-the chronology provided is an indispensable Ariadne's thread for guiding us safely through the maze of manuscripts that went into its making. But crazy though it may still seem, this singular work may nevertheless be categorized under a number of familiar headings. It offers, for instance, a powerful example of Modernist Grand Narrative, fit to set alongside Yeats's $A$ Vision and other exotic enabling fictions of early twentieth-century cultural history that allowed so many modernist writers to produce the alternative system of counter-cultural myths and symbols needed to organize their own creative work. Lawrence's master narrative is a fascinating mirror image of corresponding efforts by contemporaries such as Eliot and Pound. They created myths of Europe partly in order to criticize their America, whereas he created a myth of America partly to criticize his Europe; for there is an important sense in which Studies gives typically unconventional expression to Lawrence's obsessive concern for the condition of "England."

It is, however, a work which is most obviously addressed to America, and can be usefully set alongside other visionary versions of Americanness advanced during that period, including William Carlos Williams's In the American Grain (1925) and Hart Crane's The Bridge (1930). In particular, Lawrence satirizes Wilsonianism, the powerful political version of America's national destiny proclaimed by President Woodrow Wilson in the immediate post-war period. Just as Wilson's vision of an American-led democratic revolution worldwide was frequently used as a point of reference in recent discussions of the Bush-Rumsfeld policy of invasion of Iraq, so Lawrence's comments in 1923 on the U.S.A. anticipate the differences between commentators of our own time as they struggle to choose between materialistic self-interest (oil) and idealism (democracy) as motives for the second Gulf War:

"The old American literature! Franklin, Cooper, Hawthorne \& Co? All that mass of words! all so unreal!" cries the live American.

Heaven knows what we mean by reality. Telephones, tinned meat, Charlie Chaplin, water-taps, and World-Salvation, presumably. Some insisting on the plumbing, and some on saving the world: these being the two great American specialities. (11)

Against Wilson's epic vision of "World Salvation" as the ultimate mission of America, the 1923 Lawrence opposed his own mock-epic version of the Studies.

Comedy is at the very heart of his enterprise, but a strain of comedy which he claimed (so a note informs us) was characteristic of Indian attitudes towards whites: "[a] jeering, malevolent vibration . . ridicule. 
Comic sort of bullying. No jolly, free laughter. Yet a great deal of laughter. But with a sort of gibe in it." It is a strain that can be plainly heard in an early passage where Lawrence imagines Fenimore Cooper's tour of Europe:

"In short," he says in one of his letters, "we were at table two counts, one monsignore, an English Lord, an Ambassador, and my humble self."

Were we really!

How nice it must have been to know that one self, at least, was humble.

And he felt the democratic American tomahawk wheeling over his uncomfortable scalp all the time.

The great American Grouch.

Two monsters loomed on Cooper's horizon.

\begin{tabular}{l|l} 
MRS COOPER & MY WORK \\
MY WORK & MY WIFE \\
MY WIFE & MY WORK
\end{tabular}

THE DEAR CHILDREN

MY WORK!!!

There you have the essential keyboard of Cooper's soul. (52-53)

The final, 1923, Studies needs to be appreciated as a comic masterpiece, comedy being as instrumental to Lawrence's moral purpose as it was to Twain's.

What Lawrence regarded as the humorlessness of Americans on the matter of American-ness was for him a symptom of the fearful psychocultural repression of the true American self, the burying of it alive beneath reason, loudly asserted common-sense, and a manic will to possess the whole world through mental mastery. His savage satiric, and satyric, comedy is intended, here as throughout his fiction, to goad his readers into a reaction that would trigger liberating self-discovery. It is a strategy, and a style, strikingly reminiscent of the equally exclamatory proselytizing methods of Lawrence's American alter ego, Ezra Pound. Both writers powerfully exhibited in their finger-jabbing style a sometimes "bullying" preaching tendency that was a prominent feature of their respective cultures - young Lawrence had been chapel-going, and once an English Nonconformist always an English Nonconformist. In one sense, therefore, the style came naturally to Lawrence. But it was also a style that he can be seen perfecting over the several different versions of Studies, as he ever more consciously strives to produce the kind of punchy, streetwise idiom to which he imagined American readers were partial. After all, as the Cambridge editors point out, Studies was partly intended as Lawrence's passport to the lucrative American market (xxxi). Inscribed in the very style, as much as the content, of the work in its final form is an Englishman's vision of America - an America that Lawrence experienced in person only after his earlier, far less belligerent, versions of Studies had been written. 
We should not allow recent preoccupation with the dismantling of literary canons to deter us from appreciating the extraordinary prescience of Lawrence's anticipation of the American canon that would only be fully formed later in the century. Whereas leading American critics of his time had replaced late nineteenth-century interest in the genteel tradition with admiration for the social realist writing of the early decades of the twentieth century, Lawrence fiercely and polemically championed works by Franklin, Crêvecoeur, Cooper, Poe, Hawthorne, Dana, Melville and Whitman. Admittedly he was guided in part by the enterprising choice of texts that had been made cheaply available in Britain by Dent's Everyman Library, under the general editorship of Whitman's old friend, Ernest Rhys; but nevertheless it was, he knew, a controversial selection, not least because Americans themselves seemed to have such a relatively low opinion of these writers. Nor was British opinion of the same period much more enlightened.

In The Unusable Past, his excellent pioneering work on the ideological basis of "the influential body of critical studies of American Literature taking . . . the definition of American literature as their subject,"2 Russell Reising places Studies in Classic American Literature (1923) alongside F. O. Matthiessen's later American Renaissance (1941) and notes that "these two figures, Lawrence even more than Matthiessen, are acknowledged as the most influential founding fathers of modern American literary theory, and many other critics accept the canon as defined by them" (20). Moreover, Lawrence anticipates in Studies several of the approaches favored by many of the celebrated American critics of the twentieth century: the sweeping psycho-cultural analyses of Leslie Fiedler; Charles Feidelson's interest in the American cult and culture of the symbol; Richard Chase's emphasis on American writers' distinctive taste for non-realist, "romance" genres; Richard Slotkin's relentless tracking of the strain of violence in American cultural products; R.W.B. Lewis's fascination with the American Adamic myth; even the primacy afforded to America's westward development in the literary-cultural studies of Leo Marx and Henry Nash Smith. The striking resemblance between some of these approaches and that of Lawrence is no coincidence. Just as Studies was informed by Lawrence's passionately idiosyncratic reaction to the new "science" of psychoanalysis that became so popular among British intelligentsia after the First World War, so in the aftermath of the Second World War American literary critics were swept up in the Freudian revolution that left its indelible mark on the American poetry of the immediate post-war period. It could be justly observed, of course, that several of these critics, like Lawrence himself, were notoriously reluctant to allow the actual facts of American social, political and economic history to get in the way of a good psycho-cultural story.

"Never trust the artist. Trust the tale" (14): this is the famous principle that shapes Lawrence's own story, privileging the creative uncon- 
scious of writers as it necessarily comes into conflict with their conscious moral intentions. Great American literature, so Lawrence's master narrative runs, is written entirely in symbolic code, and its meaning is therefore never overt but always covert. The true "myth meaning" of these works is hidden because American writers are afraid to admit it, even to themselves. It is the proscribed truth that the very spirit of the American land, inarticulately felt as a deep pressure of need within every white American being, demands the emergence of a self, and a society, disturbingly different from the psychically destructive, sinister democratic order of modern, mass, dollar-driven America. The classic works of American literature are accordingly those that give unconscious symbolic expression to an otherwise hidden process. This is the violent dual struggle ongoing within the American psyche-first to slough off (the image of the snake recurs) the old European concepts of self and society, and then to realize a wholly new form of consciousness (and hence of being), which Lawrence sees as having closer affinities with Native American modes of consciousness than with those of white society. In his Studies, therefore, Lawrence sets out to track what he powerfully calls, in his essay on Franklin, "a strange and fugitive self shut out and howling like a wolf or a coyote under the ideal windows. See his red eyes in the dark? This is the self who is coming into his own" (20).

Interestingly, Lawrence locates this nascent "self" within himself, thereby revealing, intentionally or not, that his dream for America is in fact a dream of America, a dream which he dreams for himself on behalf of the future of all mankind:

Perhaps at the Renaissance, when kingship and fatherhood fell, Europe drifted into a very dangerous half-truth: of liberty and equality. Perhaps the men who went to America felt this, and so repudiated the old world altogether. Went one better than Europe. Liberty in America has meant so far the breaking away from all dominion. The true liberty will only begin when Americans discover IT, and proceed possibly to fulfil IT. IT being the deepest whole self of man, the self in its wholeness, not idealistic halfness. (18)

If one trusts the tale and not the teller, then here is a confession that Studies in Classic American Literature is a key text in Lawrence's search for what he believed to be his own "deepest whole self"; and it is certainly of himself that he speaks a little later when ostensibly discussing Benjamin Franklin:

But what we think we do is not very important. We never really know what we are doing. Either we are materialistic instruments, like Benjamin or we move in the gesture of creation, from our deepest self, usually unconscious. We are only the actors, we are never wholly the authors of our own deeds or works. IT is the author, the unknown inside us or outside us. (30) 
"We move in the gesture of creation": this is one of those beautiful, suggestively enigmatic phrases of which Lawrence is so prodigally capable when dealing with the mystery of being. It epitomizes his quarrel with psychoanalysis and its neglect of the creativity of the unconscious which, with interesting synchronicity, Freud had also begun to call das $E s$ (the IT) in 1922-1923; ${ }^{3}$ and in the poetry of its self-expression, it reminds us that Studies in Classic American Literature is essentially the work of a writer writing about writing.

Lawrence's text, however, like the American texts that he is analyzing, has its own unconscious, in the familiar Freudian sense of the word; and sometimes that unconscious can be glimpsed through the allusions with which Lawrence's text is fissured, allowing us a glimpse of an elaborate sub-text. There is, for instance, the following passage in the essay on Crêvecoeur:

The Farmer had an Amiable Spouse and an Infant Son, his progeny. He took the Infant Son-who enjoys no other name than this-

"What is thy name?
I have no name.
I am the Infant Son-"

to the fields with him. ... (33)

Five lines later, he observes that "the Amiable Spouse, who likewise in Blakean simplicity has No Name, cooked the dough-nuts or the pie, though these are not mentioned." This underlines the fact that (as the editors note with characteristic meticulousness) the verse is a parody of "Infant Joy," one of Blake's Songs of Innocence, which opens: "II have no name: / I am but two days old.'/ 'What shall I call thee?"' Indeed, Lawrence conducts a running argument with William Blake throughout Studies. He may dismiss him as a kind of honorary American, "for Blake, too, was one of these ghastly, obscene "knowers"' (73); and yet the whole of Studies is a kind of application to American texts of Blake's famous comment on Milton: "He was of the Devil's party without knowing it."

Lawrence's journey from Innocence to Experience is both the text and subtext of Studies in Classic American Literature, evident in the contrasts that he repeatedly draws between the "innocent" surface meaning of the texts and the infernal "experience" that smolders beneath. Hence the overt "diabolism" with which he opposes the maxims of Benjamin Franklin with maxims of his own, the equivalent of Blake's subversive Proverbs from Hell in The Marriage of Heaven and Hell. But the covert significance of the Innocence/Experience distinction in Studies is even more compelling. The truth that this tale has to tell, as distinct from its teller, is of Lawrence's own journey from Innocence to Experience, a 
journey he owes both to his repeated readings of what he consequently came to regard as "classic" texts and to the move to America that predated the writing of the final version. "Henri St. Jean you have lied to me," Lawrence chides Crêvecoeur; "You lied even more scurrilously to yourself. Henri St. Jean, you are an emotional liar." And he explains how he came to discover the lie: "I used to admire my head off: before I tiptoed into the Wilds and saw the shacks of the Homesteaders" (34). It is a refrain that recurs throughout Studies, confessing that its secret, unacknowledged sub-text is Lawrence's own personal journey from Innocence to Experience. To re-read the opening of the book in the light of this realization is to appreciate the force of the remark with which he begins his first chapter: "We like to think of the old-fashioned American classics as children's books. Just childishness, on our part." No wonder that Lawrence mentions, later in the text, how, as a child, he used to read the Poor Richard almanacs his father brought into the house and be thoroughly taken in by the fraudulence of Franklin's pious maxims of self-improvement. Coupled with Lawrence's recurrent interest in American "rebellion against the old parenthood of Europe" (16), this encourages us to speculate that Lawrence detected in American literature the mythic shape of his own psychic desires: his murderous instinct to visit on his parents (and thereby on his early familial and cultural milieu) the blame for a self-destructive "innocence" that had long outlasted childhood itself.

Taken as a group, the four essays on Whitman originate in Lawrence's feeling of having at last awakened from that unhealthy fascination with Whitman that characterized his earlier, belatedly adolescent self. The journey from Innocence to Experience had to be completed before these essays could even be begun. But there is also another aspect to the case. This new edition is authoritative, not least because it lays bare the complex practical factors constraining Lawrence to write and rewrite Studies in Classic American Literature for seven years. Obscenity laws, publishing outlets, touchy editors and agents, lucrative markets: all these influenced the work of a professional author already notoriously controversial and struggling to make a living. But there was also always a prior, deeper compulsion at work. Lawrence was ever the messianic writer, compelled to testify to salvific illumination. If Whitman came to regard his ever more voluminous Leaves of Grass as a secular bible not only for America but for an evolving humanity, Lawrence's literary output can be regarded as chapters in one great long Book of Revelation. However, again like Whitman, Lawrence shared the view of the religious enthusiasts of the English Commonwealth that revelation was never final but always an ongoing process of "new light." Viewed in this light, his four essays on Whitman, written in 1919, 1921-1922, 1922, and 1923, represent an ongoing process of personal development, involving a growing out of the innocence of partial understanding into a 
new, fuller experience of himself and the world. Throughout this period, Whitman was more crucial than any other American writer to Lawrence's most intimate acts of self-exploration - a fact underlined by the editors, who point out how compulsively Lawrence wrestled with Whitman's work at this time. Hence the abiding truth so resonantly affirmed in his celebrated statement of 1923: "Whitman, the great poet, has meant so much to me. Whitman, the one man breaking a way ahead. Whitman, the one pioneer" (155).

Lawrence's first mature attempt to wrestle with the personal and historical significance that Whitman held for him, however, had come ten years earlier, on December 22, 1913, in a long letter to his new friend Henry Savage; and it is a letter which anticipates many of the judgments later developed in the Studies. ${ }^{4}$ Savage was an unlikely friend for Lawrence to have found: a publican with a passion for boxing and the turf, a womaniser, Bohemian and bon viveur, he was also a poet and reviewer who had been published in The Academy, Vanity Fair and, like Lawrence himself, in The English Review. The two men had first met at Kingsgate in Kent the previous July, but almost immediately Lawrence had left for Europe, fetching up at Fiascherino on the Gulf of Spezia in North Italy, where he lived from October 1913 to June 1914. During all this time the two men had corresponded regularly, and right from the start, even while Lawrence was in England, Savage had sent him books to read. It was a gesture of friendship that Lawrence must have valued even more from abroad. Quickly the pattern established itself that Savage would post off books, and Lawrence, like a man experimenting with his recent role of literary critic, would offer his opinions of them. "I am a rotten critic," he says once after some remarks on H. G. Wells (2:74). No doubt he knew how much his own concerns differed from those of most critics of the day, including Savage himself; for this was the time in his life when he was transforming himself from the tragic novelist of Sons and Lovers to the prophetic novelist of The Rainbow and Women in Love.

It was the present job of literature, Lawrence was beginning to think, its contemporary mission, to embody the liveliness inherent in the life of the body, and to resist those conventional ideas about life that only produced a sense of unreality within the self. Of Wells, for instance, he concludes: "Not one of his characters has got a real being-Wesen-is a real being - something never localised into a passionate individuality" (2:74). He is struggling for words here, and he reaches out for the German word Wesen (being) in order to incorporate into his own writing a portion of the "passionate individuality" that he had found within himself since March 1912 when he had first met and fallen in love with 
Frieda Weekley. Such substantial being, however, was lacking both from the art and the culture of his time, and Lawrence was determined to restore it. "Sex is the fountain head, where life bubbles up into the person from the unknown," he told Savage (2:102). It was the job of the artist to celebrate such life, and the job of the critic to determine whether a work of art helps to release such life, and hence enriches the future, or whether it merely re-enacts the tragedy of the present.

Savage was clearly amazed by these "highly individual communications" from Lawrence, ${ }^{5}$ which he called "remarkable" and identified correctly as part of that work in progress that would eventually produce Twilight in Italy - and, we can now add, the early versions of Studies in Classic American Literature. Why Lawrence wrote to Savage in this way is uncertain. He was always a man who gave generously of himself in correspondence; and he was always driven to work himself out on paper. Perhaps too he cultivated Savage as a professional critic who could further his career, or as a philanderer with a failing marriage who needed his help. It was not, however, a relationship that would last. Savage wrote twice about their quarrel, which he thought "inevitable,"6 its trivial cause revealing the fundamental incompatibility between the two men. The earlier and better-known account dates it after the Armistice, but almost certainly the later version is correct, which would give a date of early July 1914 when Lawrence, back in England from Italy, wrote to arrange a second meeting (2:192-193). Savage had no illusion that Lawrence thought much of him, and he disliked Lawrence in turn because he was an "inverted Puritan" (104) who lacked humour and took life too seriously, because he was emotionally unstable, and because, suffering from an inferiority complex, he wanted disciples rather than friends. The quarrel, when it came, was over Lawrence's criticism of Anatole France and then, it seems, his disapproval of Savage's sexual mores; and it was final: "The naughty-child outburst became more and more embarrassing, and he finally flung passionately out of the room" (106). The unlikely friendship had come to an end.

The Cambridge editors pass over the letter that Lawrence wrote to Savage about Whitman on December 22, 1913, presumably considering it irrelevant to the composition of the Studies. They represent it only by one perfunctory quotation relegated to a footnote; and they ignore altogether Lawrence's comment in his next letter of January 19, 1914, that he and Frieda "have been going for Whitman - he is quite great" (2:137). It is true that Lawrence immediately qualifies his admiration by adding: "But I'd rather be alive in my own way, than in Whitmans"; but his initial comment makes two things clear-first, that Lawrence had a copy of Whitman with him in Fiascherino, presumably sent to him by Savage, and second, that in January 1914 he and Frieda were engaged in a serious and enthusiastic study of Whitman's poetry. This 
in its turn may be relevant to something that Lawrence would say later in September 1919 when he described the essays, conceived and planned in 1916-1917, as "the result of five years of persistent work" (3:400). Probably, as his editors suggest, Lawrence was thinking back to the "Study of Thomas Hardy," written five years before in the autumn of 1914, and identifying the Studies as the culmination of that first raw attempt at what he liked to call his "philosophy." But perhaps too he was thinking back to that even earlier time in Fiascherino when he and Frieda had "gone for" Whitman. At any event, there is a remarkable continuity between the position argued in the letter of 1913 and the position that Lawrence was still arguing about Whitman ten years later in the completed Studies.

Lawrence's quarrel with Whitman, he tells Savage, is also a quarrel with the innocence of his own earlier self. The American critic who later wrote of the completed Studies that they show "Lawrence struggling with Lawrence and calling it a study of America" (lxiv) might well have read this letter in identical terms; and yet such a judgment, true as it is, ignores the force both of Lawrence's literary critique of Whitman and his cultural critique of the Georgian England in which he had been brought up. Savage had written in praise of "Whitman and humanity" (2:129); and Lawrence in reply directed Savage to his own early poems in The English Review to show that he too had once felt the charm of sacrificing his own individuality to a general idea of humanity. Perhaps he had a poem like "Discipline" in mind. But such idealization of "humanity" will no longer do, he thinks, and turns to Whitman to show why. Lawrence levels four main charges against Whitman: he loves humanity in general because he cannot love men and women in particular; his bodily involvement in life is thus factitious; his love is gnawed at by sexual frustration; and his writing is a compensation for this failure to live. Whitman betrays the balance upon which human life depends, and his verse resonates so loudly only because of the hollowness of the spaces which his "passionate individuality" should have occupied. "To make an idea of the flesh and blood is wrong," says Lawrence. "The flesh and blood must go its own road" (2:129); and in that statement is a summary of all that Lawrence had learned from his eighteen-month-long relationship with Frieda Weekley and that he now wanted to pass on both to Savage and to Georgian England as a whole.

What Lawrence had learnt was that it was difficult to live with another person, and that when people speak of "love," they are often sublimating their actual emotions of love and hate, of attraction and repulsion, into a settled idea whose continuity gives them security and makes them socially acceptable. Hence his charge that Whitman's love for humanity came too easily: "don't you see," he told Savage, "he says all men are my brothers, and straightway goes into the wilderness to love them" (2:129). We can't love everyone any more than we can desire all 
women. "One doesn't feel like that." The letter is a fascinating illustration of where Lawrence was at in the winter of 1913, not least because, in loving Frieda, he was also resisting her belief in free love which had been inspired by the maverick Austrian psychoanalyst Otto Gross. "One doesn't feel like that," he might have told her, "except in the moments of wide, gnawing desire when everything has gone wrong" (2:130).

The Cambridge editors use this letter to illustrate Lawrence's "ambivalence" about Whitman ( $x x x v, n 24)$, whom he considered a "fine" writer who was "really false as hell" (2:130). Yet it seems truer to say that the letter illustrates Lawrence's awareness of ambivalence in human beings and his mixed feelings about Whitman. What is at issue here is the quality of Lawrence's critical intelligence. Ambivalence, says Charles Rycroft, "refers to an underlying emotional attitude in which the contradictory attitudes derive from a common source and are interdependent, whereas mixed feelings may be based on a realistic assessment of the imperfect nature of the object."7 The questions that Lawrence asks of Whitman are appropriate to their object; they are challenges that may legitimately be made. Savage, it seems, true to the fashion of the time, had made too great a claim on behalf of Whitman's gospel of humanity; and Lawrence wanted to put him right, not least because he had been such a man in his youth as he now accused Whitman of being - a man in whom self-consciousness subdued the capacity for spontaneous living. It is peculiarly the dilemma of a post-Romantic writer. "Whitman," he told Savage, "is like a human document, or a wonderful treatise in human self revelation. It is neither art nor religion nor truth: Just a self revelation of a man who could not live, and so had to write himself" (2:130). It was a revelation that he would gloss more fully in the sequence of essays on Whitman that he went on to write and rewrite in 1918-1923.

\section{III}

The 1918 essay that Lawrence wrote is lost; but the 1919 version survives, and is the jewel in the crown of the Cambridge University Press volume, which publishes it here for the first time. Once again Lawrence starts from the seeming paradox that Whitman may legitimately be judged both false and fine, and deliberately he sets out to show that this paradox resolves itself into a recognition of the imperfect nature of Whitman's poetry. His critique still focuses upon Whitman's subjection of the spontaneous life of the body to the self-conscious life of the mind; but the Lawrence of 1919, for all the continuity of his thought, was no longer the Lawrence of 1913-1914, and nowhere is this more obvious than in the newly esoteric character of his writing. In 1917 Lawrence had read James Morgan Pryse and H.P. Blavatsky and, like Whitman himself, had been drawn to Eastern religions and the oc- 
cult, finding in them a language which rescued subjectivity from scientific positivism, conferred prophetic authority on the déclassé poet, and appealed to a paranoid cast of mind that sought the truth in the by-ways rather than the highways of contemporary life. This esoteric writing, with all its talk of chakras, ganglia, the pineal body and so on, constitutes a very real difficulty for the reader since, like Kurtz in Conrad's Heart of Darkness, Lawrence has "kicked himself loose of the earth" upon which most of the rest of us live. ${ }^{8}$ The temptation is either to dismiss what he says about the body as medical nonsense or else to treat it as an elaborated metaphor, in the spirit of Wittgenstein's remark from the Philosophical Investigations that "the human body is the best picture of the human soul" (II, iv, 7); ${ }^{9}$ and yet in truth what Lawrence means falls somewhere between medicine and metaphor.

Lawrence's first confident statement about his faith in the powers of the body is to be found in a famous letter of January 17, 1913, to Ernest Collings:

My great religion is a belief in the blood, the flesh, as being wiser than the intellect. We can go wrong in our minds. But what our blood feels and believes and says, is always true. The intellect is only a bit and a bridle. What do I care about knowledge. All I want is to answer to my blood, direct, without fribbling intervention of mind, or moral, or what not. I conceive a man's body as a kind of flame, like a candle forever upright and yet flowing: and the intellect is just the light that is shed onto the things around. And I am not so much concerned with the things around; - which is really mind: - but with the mystery of the flame forever flowing, coming God knows how from out of practically nowhere, and being itself. (1:503)

Lawrence's words play with what Rosalie Colie calls an "epistemological paradox," $" 10$ as he talks of the wisdom of the body; applying a word that describes a mental quality to an object in the physical world. Similarly, the utterances of the blood are said to be "always true," which is disturbing if we happen to agree with Bertrand Russell that only a statement in language can have the property of truth or falsehood. Like some latter-day Puritan divine, however, Lawrence, with his nonconformist upbringing, is attending to the motions of the spirit within him (as did Whitman who, to the very end of his life, continued to revere the heterodox Quaker Elias Hicks); and yet these motions, in the new dispensation of his monistic post-Haeckel universe, are the motions of the body. Body and spirit are of the same stuff, and are to be venerated; and it is against those who prefer instead to venerate the life of the mind that Lawrence's polemic is directed.

His concern is with the problem of consciousness, and the mistaken notion that consciousness is "in" the brain. What is missing from this account is that consciousness is always consciousness of something, and that, in consciousness of our own bodies, we experience that consciousness as distributed throughout the body. Santayana wrote that 
"consciousness is the expression of bodily life and the seat of all its values"; ${ }^{11}$ he omitted to add that the body was also the seat of consciousness. Lawrence divides the body vertically into front and back, and horizontally into upper and lower. Briefly, the consciousness of the front part of the body is of love or attraction to others, and that of the back of hatred or resistance; the consciousness of the upper part of the body registers those feelings in spiritual terms, and that of the lower in sexual terms. It is neither a medical nor a metaphorical statement to say that our heart goes out towards someone or that someone puts our back up; it is a recognition that our feelings are mapped upon our body, and may well become known to us through it. The motions to which Lawrence attends are emotions, which in infancy are whole-body experiences. It may be that, as we grow older, this becomes less the case; but it is also true that different civilizations have different attitudes towards the body, and that the civilization of late Victorian and Georgian Britain was especially censorious of many aspects of bodily life. "How idiotic civilization is!" says the heroine of Katherine Mansfield's short story "Bliss": "Why be given a body if you have to keep it shut up in a case like a rare, rare fiddle?" 12 But only those who feel that they have lost their body desire to find it: Lawrence's search in Studies is in part a search for what he felt was the lost wholeness of his own body.

It is the quasi-biological quality of Lawrence's writing about the body that makes it difficult for readers to take. Medically without foundation, it hints at a paranoid sense of possessing esoteric secrets withheld even in their communication; and it rests upon an idealization of the body that Lawrence would have been quick to condemn in anyone else. The traditional distinction that prefers the soul over the body, and that becomes untenable under monism, is simply reversed, and the body becomes the source of all "wisdom" and "truth." But if body and soul are of the same stuff, why should we prioritize one over the other? And how shall we separate them within the psychosomatic unity of the human being? Lawrence's idealization of the body is nowhere shown more clearly than in the way in which he punctuates what we might call the syntax of desire and aversion. Sexual desire, for example, which in Lawrence's scheme originates in the lower part of the front body, might equally well be said to originate in the other person; and Lawrence, of course, knew this. Like all responsible advocates of spontaneity (the psychoanalyst Donald Winnicott springs to mind), he balances his theory of the bodily origins of spontaneity with a theory of relationship. The Studies are as much a book about relationship as about the self; and yet relationship too is imaged in quasi-scientific terms as electrical vibrations which pass between the different centers of two different people. Where, then, shall we say that desire starts? Lawrence's obscurantist physics of desire occludes altogether the role of the mind, and hence the role of culture, in authoring (and authorizing) desire. The complex syn- 
tax of sexual attraction is punctuated by Lawrence in such a way as to seek final authority in the authorship of the body; and it was surely his reaction against his own adolescent self-consciousness, the "horrid stream" of unremitting self-consciousness which he later described with such furious comedy in Psychoanalysis and the Unconscious, that brought him to this pass. ${ }^{13}$

The heart of Lawrence's criticism of Whitman in his letter to Savage had been that Whitman had never really got himself into life through passionate relationship with another individual human being; instead, he had had to write himself into it by means of a generalizing art that was always therefore prone to factitiousness. This had been the criticism of a young writer who had only just got into life himself by falling in love with Frieda Weekley, and was eager to put behind him a past self that seemed in retrospect uncomfortably close to that which he now recognized in Whitman. Six years later, however, in 1919, Lawrence's love for Frieda had matured and altered; he had had to think much more deeply about the kind of balance that was necessary both within the individual and within a relationship for love to survive. The famous image in Women in Love of the twin stars circling each other, held in orbit by an equilibrium between gravity and centrifugal force, is one result of this rethinking; and so too is the esoteric mapping upon the body of that balance in the Studies in Classic American Literature. In both cases, and differently in each, it was a balance complicated by what Lawrence had come to understand about bisexuality in general, and his own bisexuality in particular. His discussion is asymmetrical and chauvinist in its disregard for female bisexuality and lesbianism; but his criticisms of Whitman in 1919 can only be understood in their full coherence if read in the light of this new understanding of the body.

Whitman's attitudes towards his body and towards relationships both come under fire. He displays a "sensual negation" (362) akin to the via negativa of medieval mystics, says Lawrence; he subjects the spontaneous motions of the lower body to the knowledge and control of the mind, and turns the subsequent enlargement of his consciousness into an end in itself. His celebration of his own body is narcissistic, like that of an athlete; it is masturbatory, a fingering of the lower body to satisfy the mind. If there is perversity here, an epistemophilia like that of Hermione and Gudrun in Women in Love, it is sublimated by Whitman into spiritual love, mapped by Lawrence on the upper front of the body in the breast where we feel out hearts "go out" to the otherness of the world in sympathy and love. What Lawrence is writing here is an esoteric physiology of ecstasy, where human beings feel at one with the world and seem to know it in a spirit of love cleansed of sensuality. ${ }^{14}$ Whitman wants to merge himself with everything in the world, and this, says Lawrence, is where his view of relationship is flawed. The emotional register of human physiology is far more varied than Whitman's 
obsessive focus upon the ecstasy of the breast allows. The dialectical richness of the body's life must be respected: the self that merges ecstatically with the world may also incorporate the world imperially into itself-and still, when each of these antithetical moments of glory is passed, it remains no more than its own small self. Whitman's poetry, though great, is narrow in range, and nowhere is this to be seen more clearly than in his attitude to Woman.

Once again, as in writing to Savage, Lawrence mocks the generality of Whitman's view of Woman: one cannot enter into relationship with a generalization. What is striking about the 1919 essay, however, is its new characterisation of ambivalence. In 1913 Lawrence had described the necessary fight between two people in love, and it would have been easy in 1919 to map this vision of ambivalence upon the dialectical relationship between the front and back of the body. People are first attracted in love, and then move apart in mutual resistance: such an account would even have been in line with the psychoanalytic thinking of the day. But Lawrence's version is much more extreme. In a letter of December 1918, written after reading Jung's Psychology of the Unconscious, Lawrence had told Katherine Mansfield that Frieda had become a "devouring mother" to him (3:302); and his misogynistic fear of being swallowed up by a woman is so powerful in the Whitman essay that, whether consciously or not, he invented the word inglutination to describe it (364). The personal content of Lawrence's feeling does not prevent his essay from being even-handed in ascribing ambivalence equally to either sex; but now in 1919 that ambivalence is traced to the nature of the sexual act itself, and is mapped upon the dual function of the sexual organs of creation and excretion. The lower part of the body in both sexes is annulled in the sexual act, says Lawrence, arousing a hate that balances the access of love felt simultaneously in the upper part. There is an almost Jacobean sense of the drama of sexual intercourse here; but none of this richness does he find in Whitman, and hence, he says, the humbug of his poetry about sex.

Even more remarkable in Lawrence's 1919 essay, however, is its treatment of the homosexual component of male bisexuality. This was a subject that he had long puzzled over, as he later told Trigant Burrow (6:100), and had broached in different ways during the composition of Women in Love. But it was Whitman, he says, who helped him take "the last strides into freedom" (369). The meaning of this intriguing phrase is uncertain, but includes the idea that, like Birkin in Women in Love, he has suddenly reached a point in his life where he need no longer deny his feelings for men. What beside Whitman had brought him to this point is not clear. Perhaps it was partly resistance to Frieda, partly his feelings for William Henry Hocking (and other men before him), partly an attempt to deal with his own violent hostility towards the upper-class 
homosexuality he had recently encountered at Cambridge, and partly too perhaps a wish to develop his own ideas about the bisexuality that was now common parlance amongst his psychoanalytic friends. ${ }^{15}$ These ideas, however, proved to be idiosyncratic, and Whitman's example was as much cautionary as it was inspirational.

What Lawrence found in Whitman were grounds for his new faith that the way forward out of the impasse of the present, personally and historically, was through the love of man for man, which he saw as a rediscovery of an ancient tradition known to esoteric priesthoods centuries before Plato. This distinction between the esoterics and the Greeks was important to Lawrence since it enabled him to dissociate himself both from "Greek paiderasty" (which he criticized variously as fusion, domination or prostitution) and from his Cambridge acquaintances who practiced it. Such homosexuality, he thought, neglected the sense of otherness, the true polarized opposition, upon which equality in relationship depended. Once again Lawrence's body-map matters here. He maps homosexual love upon the body at the root of the spine, just above the anus, which, like the vagina, he describes as a "port, of egress and ingress" (366) where love and hatred, creation and excretion, are manifested in a balanced process that maintains a polarized relationship. It is here that Lawrence's two great disagreements with Whitman become clear. First, he attacks him for confounding singleness and polarization of being with a desire to merge with the beloved; it was this confusion, he says, that made Whitman so great a poet of death or, in the language of 1913, so interesting a "human document." Second, in a rethinking of his 1913 critique of Whitman's faith in "humanity," he attacks him for seeing in comradeship the model of a democratic politic that denies the essential disequality of human beings. This attack was muted in Lawrence's 1919 essay, and may be sensed only in the way that his metaphor of polarized equality enabled him to speak of the positive and negative poles of a relationship. It was, however, a line of thought that he developed in the four essays on "Democracy" written in September and October of 1919 in direct response to Whitman's essay on the same subject, and later still in Aaron's Rod and Kangaroo where, partly influenced by Whitman, he went on to explore the politics and the psychology of leadership and discipleship.

Lawrence's essay ends, however, in praise of those moments when Whitman's poetry reveals "sensual impulse instant with spiritual impulse, and the mind serving, giving pure attention." The eloquence of the writing here embodies his response as a reader to verse in which "the whole soul speaks at once." This is what T. S. Eliot would later call "the complete consort dancing together"; and yet there are moments of discord in Lawrence's writing too that give us room for pause. It is odd, for instance, to see him insist that homosexual relationships, polarized at the root of the spine, should be "beyond emotion," "almost 
beyond feeling" (366). Only a man who is afraid of emotion and feeling wants to be without them. It is possible that Lawrence could only admit his homosexual component by denying its emotional content - and hence his insistence that the impersonality of desire remain uncontaminated by personal feelings and emotion. Elsewhere, however, Lawrence makes this demand of heterosexual love, too; and this raises the more general possibility that the whole of his conceptual map of the human body, as well as the intractability of the prose in which it is described, even as they offer an integrated picture of the physiology of human feeling, also fulfill a subsidiary unconscious desire to dissociate different parts of the body from one another, to fence off different areas of feeling. This is a possibility that threatens the very ground upon which the 1919 Studies are raised, and suggests that Lawrence's transition from innocence to experience had not been as successful as he would have liked to think.

\section{IV}

The next important version of the Whitman essay to survive is that of 1921-1922, printed as Appendix V by the Cambridge editors. Although this new version is lengthier and more expansive in exposition than its predecessors, Lawrence's critique of Whitman is substantially unchanged. What is new is the use to which he puts it. His sense of the co-existence of love and hate in heterosexual relations has relaxed into a vision of what he now calls the systole and diastole of love, the inevitable rhythm that draws lovers together in desire before separating them into singleness again; and the great new question which this essay addresses is the question of what men should do when they separate away from women. If women commonly occupy themselves with children, asks Lawrence in his chauvinist way, what ought men to do?

Once again Lawrence turns to the language of comradeship in his answer, but in an argument significantly different from that of 1919; once again he has moved on, still using Whitman to help him on his way. The overt homosexual interest of the 1919 essay has now gone altogether, replaced by an idealization of manhood that varies between the naive, the absurd, the paranoid, and the politically irresponsible. What made Lawrence abandon his homosexual concerns of 1919 is impossible to determine. The simplest explanation is the likeliest, that the issue ceased to be a matter of personal urgency to him. But it may also have been his sense of what he knew was publishable; and in this case it is possible that Whitman's language of comrades still continues to conceal as much as it makes plain, and that Lawrence's essay has a homosexual sub-text.

Equally, we cannot know what inspired Lawrence's idealization of manhood in the new 1921-1922 essay. It may have been, consciously or unconsciously, a sublimation of homosexual desire, or even a tacit ac- 
knowledgment of it; it may have been over-compensation on the part of a frail non-combatant in the recent war; or it may have been an oedipal need to avoid "inglutination" in his married life, to invent for himself the male role-model that he had found only fitfully in his early life. Man is now "the unthinkable warrior, creator, mover and maker" (413). While women raise the children, his work is to build a new world, and to do it in association with his comrade, David with Jonathan and Orestes with Pylades. In 1921-1922 Lawrence makes explicit the belief that had only been implicit in the 1919 essay, that comradeship between men is not a matter of democratic equality but of leadership and discipleship. Pairs of friends must unite in "a hot belief" in each other (415), with each pair, and each pair of pairs, consisting of a leader and a follower, in a pyramid that would eventually culminate in "the final leader of men, the sacred tyrannus" (416). It was this lurid vision that Lawrence explored, and scrutinized, in Aaron's Rod, completed in May 1921.

At the start of September 1922 Lawrence realized an old dream when he first set foot in the United States; and one of the first things that he did there was to recast the Studies completely, in readiness for American publication. They were shortened, their esoteric framework was dropped, and the writing made much snappier. He was "Americanising" them, he said (li), in an idiom which, even if "too violent" for some, was "the first reaction on me of America itself" (lii). The new version of the Whitman essay, its penultimate version and printed as Appendix VI in the new Cambridge edition, was particularly sharp, a deliberately unpleasant and "personal" attack upon Whitman himself (424). The 1921-1922 version had confined its praise for Whitman's poetry almost entirely to two short paragraphs perfunctorily tacked on at the end. Now in 1922 the praise has contracted still further into descriptions of him as "a very great poet, of death, not of life" (428). Lawrence's new essay is satirical, embodying in exemplary fashion the principle of resistance which he finds lacking in Whitman, with his obsessive desire to merge. It is a satire not only of the "false exuberance" of Whitman (423) but of America too, as epitomized in the eye-catching headlines of its journalism and the brash certainties of its democratic self-conceit: "DEMOCRACY! THESE STATES! EIDOLONS! LOVERS, ENDLESS LOVERS!” (421). Like all Americans, Lawrence implies, Whitman is an "impudent provincial" with only a "rather sketchy knowledge" of the world that he presumes to know and love (424). Writing out of racial stereotypes of his own, Lawrence asks what Whitman knows, for instance, of Eskimos, and imagines his answer: "Who is he that demands petty definition? Let him behold me sitting in a kyak" 
(424). It is a parody that merges with its subject only to withdraw in subversive mockery. If the 1921-1922 essay had shown a Whitman in whom "even hate is love" (406), its 1922 revision shows Lawrence's love in the process of being transformed into hate.

At its heart lies a scurrilous picture, probably told to Lawrence by Dorothy Yorke, ${ }^{16}$ of Whitman as an old man walking naked in his back yard, "fat and excited with his own nudity and his grey beard," and stopping the little schoolgirls coming home "with senile amorousness" (423). This ugly tale is used by Lawrence emblematically as the centerpiece of a demented Swiftian carnival in which the normal processes of the body go mad. Everything is confounded, as Lawrence's imagination runs amok amongst monstrous fantasies of Whitman's physical perversity. If he made love to a woman, says Lawrence, he'd ooze into her womb and then make his escape through the back door. His poems are acts of masturbation, the ejaculations of a man "tainted with the "exposure' dementia" (425). His digestive system too has broken down and, in a set of images deriving from a back-yard privy, Lawrence pictures him sitting on infinity as on a toilet-seat, excreting himself. The ecstatic afflatus of his verse recalls a frog blown up through a straw inserted into its anus. Whitman is a "white flux" (426), a diseased sexual discharge secreting itself in ghoulish post-mortem poetry and gloating, like some latter-day Weird Sister, over its "horrible pottage of human parts" (421). The particular loves and hates, the idiosyncratic likes and dislikes which are the life of the individual human body are drowned in the cesspool of infinity. MERGE, says Whitman. MERDE, replies Lawrence.

Despite this attempt to evacuate Whitman's vision from his system, however, Lawrence accepts his own implication in the monstrousness of what he has imagined. In the conclusion to this 1922 essay, unlike anything in any earlier version, he takes full responsibility for his fantasies. This is the author of Aaron's Rod and Kangaroo, disenchanted with the mess that everyone, including himself, has made of human relationships. "We have died, and we are still disintegrating," he says (429), and all that we can do in the meantime is to possess our souls in singleness and quietude, waiting for new life to emerge. It is Whitman's value as a "human document" that, unwittingly, he has revealed the inadequacy of all modern forms of love-heterosexual, homosexual and Christian democratic love alike. But life at its deepest level, says Lawrence, lies beyond relationship, in the motions of the Holy Ghost within the individual body and in the depths of the individual soul. In this new stage of his disillusion, he has come to a place known to many mystics, and charted by Donald Winnicott in his essay "Communicating and Not Communicating Leading to a Study of Certain Opposites," which argues that "each individual is an isolate, permanently non-communicating, permanently unknown, in fact unfound." 17 In the last analysis, 
says Lawrence, chauvinist to the end, we stand alone in "stark isolation" (429), beyond the scope of Jesus; and here, in this isolation, we must keep our "silent loyalties" (428), attending upon the Holy Ghost and acknowledging the new hierarchies that it will bring amongst men.

\section{VI}

There was much in this 1922 version of the essay to cause a publisher anxiety, and in the late spring of 1923, at proof-stage, Lawrence rewrote the essay for one last time. This was its final version as published in Studies in Classic American Literature, and it removed the story of Whitman in his back yard and, with it, all explicit excretory references, and almost all the sexual references too. It is true that two passages were added which describe Whitman's mentalization of his Moby Dick, the "lonely phallic monster" of his sensual self (150), but the essay is no longer a grotesque carnival of the dysfunctional body. Its conclusion too has been cut, with its references to Jesus as "an intermediary god" (429) and its recommendations to renounce sex in order to wait upon the Holy Ghost. Instead, showing his versatility, Lawrence has added six pages that introduce us to a quite new Whitman in a quite new spirit of respect. "Whitman, the great poet, has meant so much to me," he begins (155) and, although his criticism remains sharp, it is generous. The clue to this new conclusion is the page of anti-American satire inserted into the first part of the essay, where Lawrence imagines Whitman's poetry as an automobile driven at night in the headlight of a single fixed idea ("ONE IDENTITY"), and ignoring all other forms of life there in the dark. Whitman may have been the poet of the Open Road, but there are "myriads of ways in the dark, not to mention trackless wildernesses" (152) which he ignores. Perhaps this new poet of the Open Road was a Whitman whom Lawrence had discovered since coming to America; but it was also a Whitman through whom he could continue to discover himself.

What Lawrence found in Whitman in 1923 was the first poet of a new dispensation which placed the soul in the body, the pioneer of a new gospel which found the purpose of life not in salvation but in living itself. Whitman awoke new desires, says Lawrence; he changed the blood of people rather than their minds. "He was the first to smash the old moral conception, that the soul of man is something 'superior' and 'above' the flesh" (156). To Lawrence the soul is the voice of the body speaking in the moment of its desire; it is an existential wayfarer along the open road, seeking no destination and with no purpose other than that of its own fulfillment through truth to its own desires. But desires, rightly understood, are also relationships, and Lawrence honors Whitman for the sympathy which both men saw as the true principle of relation- 
ship. But here, says Lawrence, was Whitman's great mistake, that made him a false prophet: his "sympathy" was tainted by the gospel of the old dispensation which glossed it in terms of Christian love and Pauline charity. The Biblical rhythms of Lawrence's prose throughout this 1923 passage announce him as the prophet of a newer dispensation still, whose gospel is that sympathy includes hate. "Even satire is a form of sympathy," says Lady Chatterley's Lover; ${ }^{18}$ it eliminates harmful things from the psyche-soma. The problem comes, of course, when we take this innate "morality" of the psyche-soma and turn it into a social ethic. Lawrence tells us tout court that the right sympathetic response to a syphilitic woman who wants to infect men is to kill her. But Max Weber pointed out the fallacy here when he dismissed Otto Gross's belief in acting out desire in order to avoid the neurological damage of repression: namely, that morality is not a branch of hygiene, and that what ought to be cannot be deduced from what is. ${ }^{19}$

This celebration of Whitman's morality of the Open Road tells us something of where Lawrence found himself in 1923 and provides an index of how far he had travelled, both literally and metaphorically, in the ten years since Savage had sent him that copy of Whitman in 1913. In the first place, of course, it is a morality well suited to the traveller who, since the war, had lived in Italy, Germany, Ceylon, Australia, and the United States, and who was now living in Mexico; and in the second place, it is a morality well suited to the genre of fiction that he had been writing during those years: the picaresque. We know that Lawrence had long been thinking about the meaning of picaresque. During the revision of Women in Love begun in March 1917, for instance, he had added the two following paragraphs about Birkin to the start of the chapter called "Excurse"; 20 and it may even be that he added them in response to reading the Everyman Whitman he had acquired at the start of January, preparatory to his work on Studies in Classic American Literature:

His life now seemed so reduced, that he hardly cared any more. At moments it seemed to him he did not care a straw whether Ursula or Hermione or anybody else existed or did not exist. Why bother! Why strive for a coherent, satisfied life? Why not drift on in a series of accidents-like a picaresque novel? Why not? Why bother about human relationships? Why take them seriously-male or female? Why form any serious connections at all? Why not be casual, drifting along, taking all for what it was worth?

And yet, still, he was damned and doomed to the old effort at serious living.

Life can only be understood as narrative, and the contrast that Birkin draws here is between ways of living and of writing, between what he calls the "old effort at serious living" and a new way that he identifies in terms of picaresque fiction.

The "old effort at serious living," the struggle to achieve "a coherent, satisfied life," involves Birkin in taking human relationships with the same kind of seriousness that Lawrence himself shows in Women in 
Love. He had told Savage in 1913 of his "battle" with Frieda, and of his sense that art should be "like a battle song after a battle" (2:130). Women in Love celebrates that battle at a later stage. It is the fictional record of his struggle in 1916-1919 to achieve balance and integration, to attain coherent expression of a bisexuality understood both in its psychosomatic ground and in its cultural moment. The esoteric writing of the 1918-1919 Studies records another such struggle. But, Birkin reflects, there are other ways to live, other stories to tell oneself; one might just "drift on in a series of accidents-like a picaresque novel." Earlier in the novel, Birkin had decided that "he did not believe that there was any such thing as an accident. It all hung together, in the deepest sense" (26). But now he acknowledges a narrative form which privileges the accidental: "Why not be casual, drifting along, taking all for what it was worth?" Here Lawrence anticipates the fictional form of the novels that he would write in 1917-1921: The Lost Girl, the unfinished Mr. Noon, and Aaron's Rod. Whether Whitman influenced Lawrence's conception of these novels or not, he certainly provided retrospective justification for them. The philosophy of the Open Road expounded in the 1923 essay provides the perfect ideological rationale for adapting the old picaresque form to new existential ends. Lawrence saw in Whitman's "heroic message" to the soul an epitome of his own fictional aim: "She is to go down the open road, as the road opens into the unknown, keeping company with those whose soul draws them near to her, accomplishing nothing save the journey, and the works incident to the journey, in the life-long travel into the unknown, the soul in her subtle sympathies accomplishing herself by the way" (157).

What attracts Birkin to the picaresque at this moment in Women in Love, however, is its irresponsibility; the "old effort at serious living," by contrast, feels heavy with responsibility, like a doom. The question that this raises is whether Lawrence's picaresque experiment of 1917-1921 is similarly irresponsible, and whether the comparative failure of the novels expresses a failure of living in the author. This is a question too complex to enter upon fully here; but what we may say with certainty is that each of these novels, for different reasons, gives up on the effort to sustain the full range of relationship with which Lawrence had struggled in Women in Love and the 1918-1919 Studies in Classic American Literature. In particular, they all give up on the relationship between man and woman in its full range and richness; even $M r$. Noon, which set out to tackle this very problem, remains incomplete. The picaresque has been predominantly a masculine form in our culture, and it seems no accident that Lawrence's picaresque fiction belongs to his most masculinist phase as a writer. In this respect we may conclude that Whitman, and his love of comrades, had a disintegrative effect on Lawrence, and that this disintegration is expressed in the 1923 essay by the space between 
its satirical disgust at the modern world and its radiant idealization of Whitman as the prophet of the Open Road. For it is in this space between disillusion and idealization that we look for the realization of human relationship; and in the 1923 essay this space is empty. "Generalisations are no good to the individual," Lawrence had told Savage in 1913 (2:130). It was not until Lawrence wrote The Virgin and the Gipsy and began Lady Chatterley's Lover in 1926 that this empty space was once again adequately filled in his fiction.

\section{University of Wales, Swansea}

\section{NOTES}

1 Ezra Greenspan, Lindeth Vasey, and John Worthen, eds., Studies in Classic American Literature (Cambridge: Cambridge University Press, 2003), dust jacket. All references will be to this edition.

2 Russell Reising, The Unusable Past: Theory and the Study of American Literature (New York and London: Methuen, 1986), 1.

3 See The Standard Edition of the Complete Psychological Works of Sigmund Freud, vol. 18 (London, The Hogarth Press, 1955), 234.

4 George J. Zytaruk and James T. Boulton, eds., The Letters of D. H. Lawrence, Volume 2 (Cambridge, Cambridge University Press, 1981), 129-130. Subsequent references both to this and to other volumes of the letters, diversely edited, will appear parenthetically in the text.

5 See his 1930 memoir published in Edward Nehls, ed., D. H. Lawrence: A Composite Biography, Volume 1 (Madison: University of Wisconsin Press, 1957), 210. The following quotation is from his autobiography The Receding Shore: Leaves from the Somewhat Unconventional Life of Henry Savage (London: Grayson \& Grayson, 1933), 105.

6 The two accounts are in his 1930 memoir and his 1933 autobiography, from which this quotation comes (106). The following two references are also to this work.

7 Charles Rycroft, A Critical Dictionary of Psychoanalysis (Harmondsworth: Penguin Books, 1972), 6.

8 Joseph Conrad, Heart of Darkness (Harmondsworth: Penguin Books), 107.

9 Ludwig Wittgenstein, Philosophical Investigations, trans. G. E. M. Anscombe, $2^{\text {nd }}$ edition (Oxford: Blackwell, 1958), Part II, section iv, point 7.

10 Rosalie Colie, Paradoxia Epidemica: The Renaissance Tradition of Paradox (New York: Princeton University Press, 1966), 6.

11 Logan Pearsall Smith ed., Little Essays Drawn from the Writings of George Santayana (London: Constable \& Co., 1920), 16.

12 Katherine Mansfield, The Collected Short Stories (Harmondsworth: Penguin Books, 1981), 92.

13 D. H. Lawrence, 'Fantasia of the Unconscious' and 'Psychoanalysis of the Unconscious' (Harmondsworth: Penguin Books, 1971), 203. 
14 In $M r$. Noon Lawrence returned to the subject of ecstasy in a satire against spooning: "All Whitman's Songs of Himself and Other People lie in the hollow of a spoon. If you seek the Infinite and the Nirvana, look not to death nor the after-life, nor yet to pure abstraction: but into the hollow spoon." See Lindeth Vasey, ed., Mr. Noon (Cambridge: Cambridge University Press, 1984), 24.

15 We draw here upon Mark Kinkead-Weekes's considered discussions of Lawrence's attitudes to homosexuality in his D. H. Lawrence: Triumph to Exile 1912-22 (Cambridge: Cambridge University Press, 1996); see especially 213-215 and 376-381.

16 See the editors' note to 423:16 (Studies, 540).

17 D. W. Winnicott, "Communicating and Not Communicating Leading to a Study of Certain Opposites" (1963), in The Maturational Processes and the Facilitating Environment (London: The Hogarth Press, 1965), 187.

18 D. H. Lawrence, Lady Chatterley's Lover, ed. Michael Squires (Cambridge: Cambridge University Press, 1993), 101.

19 See Weber's long letter of September 13, 1907, to Edgar Jaffe in Marianne Weber, Max Weber: A Biography, trans. Harry Zohn (New York: Wiley-Interscience, 1975), 375-380.

20 D. H. Lawrence, Women in Love, ed. David Farmer, Lindeth Vasey and John Worthen (Cambridge: Cambridge University Press, 1987), 302. 